\title{
Afrocentric Attitudinal Reciprocity and Social Expectations of Employees: The Role of Employee-Centred CSR in Africa
}

\author{
Oluseyi Aju ${ }^{1} \cdot$ Eshani Beddewela $^{1}$ (D)
}

Received: 31 August 2018 / Accepted: 30 October 2019 / Published online: 14 November 2019

(c) The Author(s) 2019

\begin{abstract}
In view of the limited consideration for Afrocentric perspectives in organisational ethics literature, we examine EmployeeCentred Corporate Social Responsibility (EC-CSR) from the perspective of Afrocentric employees' social expectations. We posit that Afrocentric employees' social expectations and the organisational practices for addressing these expectations differ from conventional conceptualisation. By focusing specifically upon the psychological attributes evolving from the fulfilment of employees' social expectations, we argue that Afrocentric socio-cultural factors could influence perceived organisational support and perceived employee cynicism. We further draw upon social exchange theory to explore rational reciprocity (i.e. attitude and behaviour) evolving from the fulfilment and breach of employees' social expectations at work. Contrary to the rational norm of reciprocity, we identify a reciprocity norm within which the breach of employees' social expectations could in fact engender positive reciprocity rooted in esan reciprocity ideology—an ideology that emerged from the ethical tradition of the Yoruba people from Nigeria, West Africa. Overall, our paper elucidates the implications of Afrocentric peculiarities for employees' social exchange within the African workplace, thus extending the present understanding in this regard.
\end{abstract}

Keywords Employees' social expectations $\cdot$ Employee-centred corporate social responsibility $\cdot$ Social exchange $\cdot$ esan reciprocity ideology

\section{Introduction}

African cultures are considerably similar, mainly in terms of the pervasive preference of the African people for community life (Agulanna 2010; Mbigi 2005; Menkiti 1984). In effect, the African way of life suggest that 'people are not individuals, living in a state of independence, but part of a community, living in interdependent relationships' (Turaki 2006, p. 36). Indicatively, an African is less resilient as a lone individual, but may be greatly resilient as a community member. The sense of community amongst Africans further resonates with the ubuntu philosophical aphorism: 'umuntu ngumuntu ngabantu' which is translated as 'I am, because we are; and since we are, therefore I am' (Mbiti 1969, p. 106). The penchant for community life is so pervasive in

Eshani Beddewela

e.s.beddewela@hud.ac.uk

Oluseyi Aju

Oluseyi.Aju@hud.ac.uk

1 Huddersfield Business School, University of Huddersfield, Queensgate, Huddersfield HD1 3DH, UK
Africa such that the emphasis on 'humanity and relationships' exceed the emphasis on 'material wealth' (Shonhiwa 2006, p. 6). Besides, African communal instinct as encapsulated in ubuntu philosophy (and other Afrocentric ethics) have positive implications for 'compassion, reciprocity, dignity, harmony and humanity in the interests of building and maintaining community' (Nussbaum 2009, p. 100).

Thus, a pervasive expectation that certain institutions (for example, family, government, educational and corporate institutions) are in effect responsible for meeting the communal needs of the people is ingrained within African societies (Agulanna 2010). For example, an individual carrying out his social and economic obligations within the Igbo society of south-eastern Nigeria expects his/her community to positively reciprocate by providing him/her with the required social support (Agulanna 2010). In the precolonial Igbo society, community members shared both joy and sorrow together with the entire village, leading to a more fulfilled life, even if it was lacking in material comforts (Udeze 2009). These deep-rooted prosocial behaviours in African communities may have fundamental influences on the expectations of indigenous African employees. 
Nevertheless, there are significant problems associated with the organisational support provided for the indigenous African worker, with ubiquitous social deprivation prevalent in the African workplace. ${ }^{1}$ For example, sub-Saharan Africa has constantly recorded higher rates of working poverty, with $33.6 \%$ of all employed people living in extreme poverty in 2016-i.e. on less than US\$1.90 per day-and an additional $30.1 \%$ in moderate poverty-i.e. between US $\$ 1.90$ and US\$3.10 per day (International Labour OrganisationILO 2017). Besides, there are concerns as to the ability of political institutions to uphold employees' rights in the workplace (Graham et al. 2016). As of 2017, the Nigerian parliament, for instance had not ratified 58 ILO's conventions on labour market governance, with further drawbacks in legislating labour laws supportive of workers (ILO 2017a). This governance gap has provided employers with ample opportunity to compromise employees' rights even in sectors that are critical to national survival.

Indigenous African workers have been driven to engage in persistent labour strikes across Africa (Aye 2017; Chinguno 2013), with employees trying to reaffirm their power and claim their due benefits from employers. For example, many strike actions have been undertaken in the Nigerian oil industry, where the two labour unions: Petroleum and Natural Gas Senior Staff Association of Nigeria (PENGASSAN) and the National Union of Petroleum and Natural Gas Workers (NUPENG) have over the years resorted to strike actions to protest poor working conditions (see Aye 2017). Similar labour conflicts have been prevalent in the SouthAfrican mining industry. For instance, on 16 August 2012, the South-African Police Service (SAPS) opened fire on a crowd of striking mineworkers at Marikana. The open fire assault lead to the death of 34 mineworkers, while 78 workers were severely injured, with 250 of the miners arrested (Alexander 2016; Marikana Commission Inquiry Report 2015).

The International Labour Organisation (ILO) has recognised the presence of a cycle of neglect of employee rights, recommending the need to strengthen the capacity of labour governance throughout the African region through the adoption of the 'Decent Work Agenda' (see ILO 1999). The Decent Work Agenda promotes 'jobs [that are] decent, workplaces that are inclusive and where workers have a voice to

\footnotetext{
1 The cause of social deprivation in the African workplace despite the prosocial behaviour of early Africans remains unfounded. There is an allegation that colonialism distorted communal values in Africa (Murithi 2006), with a form of 'jettisoning' of African indigenous traditions (Akinola and Uzodike 2017, p. 93). Similarly, Udeze (2009) suggests that "colonisation introduced a different class of people or social status based on wealth, education, politics to name a few. Africans failed to manage the sudden change of societal values by foreign culture to their advantage' (p. 53).
}

stand up for their rights' (Ryder 2015, p. 4). In this regard, Employee-Centred CSR (EC-CSR), aligns with the Decent Work Agenda of the ILO, as it comprises of 'organisational practices aimed at fulfilling employees' social expectations with the purpose of creating quality of working life and workplace harmony'.

Accordingly, given the ingrained socio-cultural roots in the African workplace, and the prevalent deficiencies in worker's rights and social welfare, one has to understand what the indigenous African worker expects from his/her employer in order to understand how EC-CSR can be effectively fulfilled. Nevertheless, employees' social expectations, i.e. how employees perceive their work environment and their future development within the company (Aguilera et al. 2007, p. 6), have thus far been neglected by EC-CSR scholars (e.g. Barrena-Martínez et al. 2017; Mory et al. 2016, Peterson 2004; Shen and Zhu 2011). More remarkably, the infiltration of African cultural values into the dynamics of employment relationships within the African workplace, has been unacknowledged in extant debates.

In view of the above, our aim in this paper is to discern the reciprocal relationship that might occur if employees' social expectations are fulfilled and breached, specifically within the African workplace. To achieve this aim, we integrated conventional literature on the themes of EC-CSR, psychological contract and social exchange, with fragmented Afrocentric literature to explain conventional and Afrocentric expectations of employees regarding EC-CSR and the conventional and Afrocentric reciprocities that might evolve when these expectations are fulfilled and breached. Accordingly, the objectives of this paper are fourfold:

(a) To explore the dynamics of employees' social expectations from the perspective of the psychological contract, and the perceived EC-CSR practices for addressing these expectations in the Afrocentric workplace;

(b) To juxtapose conventional conceptualisations of perceived organisational support and perceived employee cynicism with Afrocentric conceptualisations of the same subject matter;

(c) To explore the conventional/rational reciprocity evolving from the fulfilment and breach of employees' social expectations in the Afrocentric workplace.

(d) To explore Afrocentric reciprocity that might evolve from the breach of employees' social expectations in view of esan reciprocity ideology-an ideology that emerged from the ethical tradition of the Yoruba people from Nigeria, West Africa.

We aim to contribute to extant literature on the Afrocentric employee-organisation relationship in the following ways. First, by identifying the contrast between Afrocentric employees' social expectations (perceived psychological 
contract) and the conventional organisational practices for addressing these expectations (i.e. EC-CSR), we demonstrate the implications of socio-cultural exigencies for employees' social expectations at the workplace. From the policy perspective, the paper highlights the need for ECCSR policy makers to acknowledge and integrate sociocultural requirements to their policy development process. Second, we extend the present understanding of employee psychology, by integrating conventional and Afrocentric literature to explain the influence of the fulfilment and breach of employees' social expectations on perceived organisation support and perceived employee cynicism respectively. This integrative dimension to theorisation stimulates our understanding of the dynamics of positive and negative reciprocity from the conventional and Afrocentric perspectives. Finally, and most importantly, we explicate the implications of the Afrocentric ethical ideology for social exchange in the workplace.

Specifically, we argue that there exists peculiar instances where breach of employees' social expectations could in effect engender positive reciprocity within the Afrocentric workplace. This peculiar reciprocity stance is ascribed to esan reciprocity ideology, which emerged from Odu Ifa; the ethical corpus of the Yoruba people from Nigeria, West Africa (see Balogun 2013; Elebuibon 2004; Fasola 2015). For clarity, the Yoruba people, consist of about 30 million people of whom live in south-western Nigeria today, with enclaves and diasporas in other African countries and beyond (Akintoye 2010). According to Apter (2018 as cited in Matory 2019):

Yoruba culture overwhelms the other African-diaspora cultures it encounters in the Americas, and both the Haitian state and the gender relations of the Brazilian plantation have assumed its shape. [...]. Several other aspects of Yoruba culture also endure in the Americas. One is syncretism, or the Afro-Latin American practice of correlating African gods with Roman Catholic saints, and the use of the latter in rites for the benefit of the former (p. 111).

Apter's narrative above suggests that although esan originated from the Yoruba ethical tradition, its ideological overtones may reverberate in other parts of Africa and Africadiaspora culture. Furthermore, Odu Ifa is referred to as the sacred text of the spiritual and ethical tradition of the Yoruba people (Karenga 1999). The divinity of Odu Ifa was captured in the account of Karenga (2012) thus:

Nowhere is the profundity and beauty of African spirituality more apparent than in the Odu Ifa, the sacred text of the spiritual and ethical tradition of Ifa, which is one of the greatest sacred texts of the world and a classic of African and world literature. Its central message revolves around the teachings of the goodness of and in the world; the chosen status of humans in the world; the criteria of a good world; and the requirements for a good world'. (Karenga 2012, p. A-7)

We are not unconscious of the fact that Africa is a large continent with several nations who have diverse cultures, languages and dialects. Notwithstanding the diverse background of Africa, 'there are many basic similarities in the religious systems-everywhere there is the concept of God (called by different names); there is also the concept of divinities and/or spirits as well as beliefs in the ancestral cult. Every locality may and does have its own local deities, its own festivals, its own name or names for the Supreme Being, but in essence the pattern is the same. There is that noticeable "Africanness" in the whole pattern' (Awolalu 1976, p. 2).

Prior to contextualising the propositions underpinning the above-mentioned contributions, we provide insights into EC-CSR below.

\section{Employee-Centred Corporate Social Responsibility}

Employee-Centred CSR (EC-CSR) have in recent times been conceptualised from different but related perspectives. For instance, it has been referred to as socially responsible human resource management (SR-HRM) comprising of three components of 'labour law-related legal compliance HRM; employee-oriented HRM and general CSR facilitation HRM' (Shen and Zhu 2011, p. 3022). While the legal compliance HRM requires firms to propagate action with regard to issues of health and safety, equal opportunity, working hours, minimum wage and the use of child or forced labour, the employee-oriented HRM focuses on providing for employees' social needs such as training and professional development, mentoring, employee participation and involvement (ibid.). The general CSR facilitation HRM are operational HRM functions aimed at facilitating both internal and external CSR programs. In contrast to Shen and Zhu's (2011) interpretation, Mory et al. (2016), defines EC-CSR more narrowly, as comprising of 'socially responsible behaviour by a company towards its employees' (p. 1394), encompassing activities such as; employee development, diversity, employee empowerment and creating a positive working environment.

Hence, while both definitions perceive EC-CSR as an organisational practice aimed at fulfilling employee needs beyond those dictated by legal requirements, Mory et al. (2016), firmly disassociates EC-CSR from organisational concerns for employees' economic expectations, as delineated through the employment contract to those concerns 


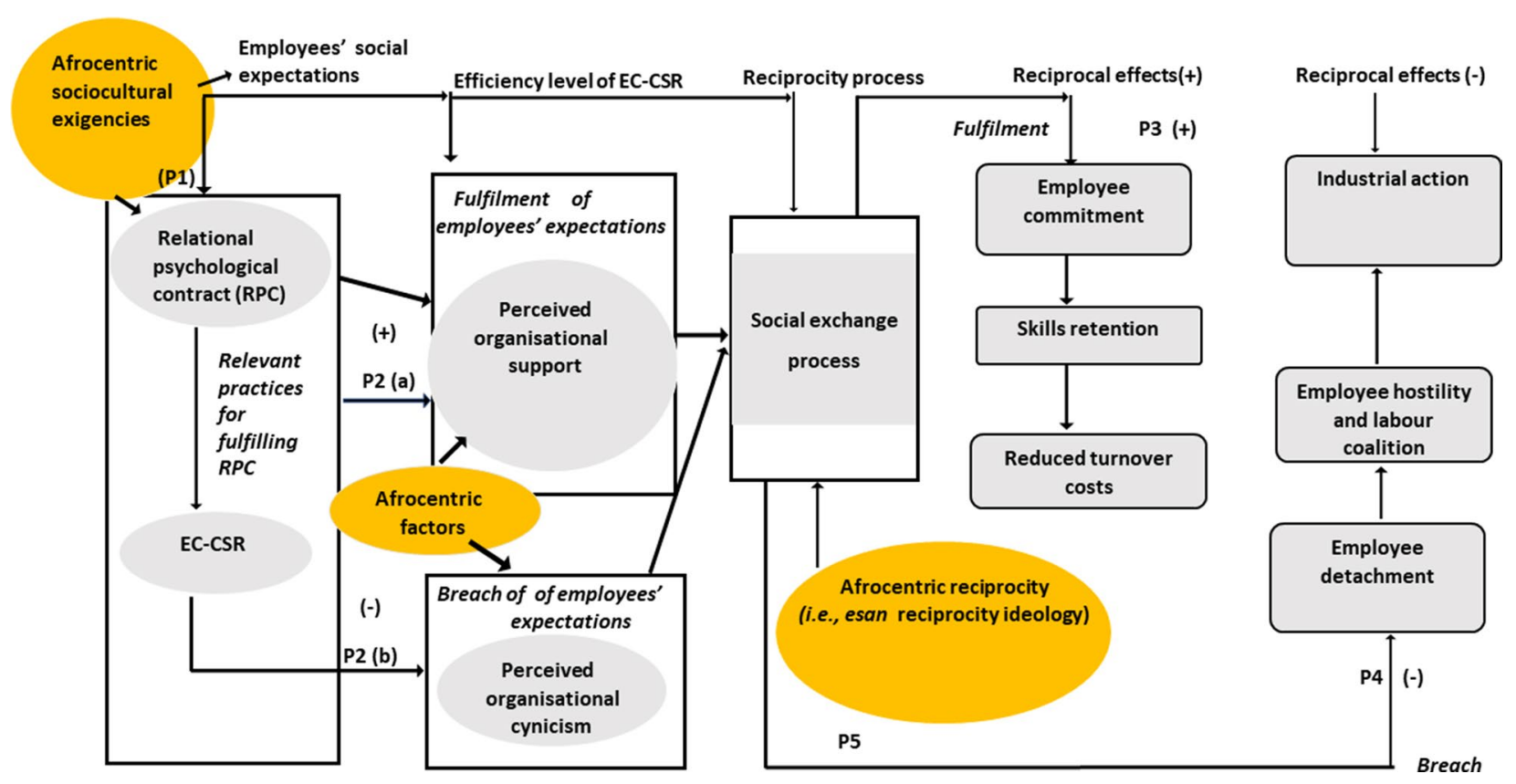

Fig. 1 Afrocentric EC-CSR model

related to employees' social expectations, thereby, aligning well with our own conceptualisation of EC-CSR (see Fig. 1).

In another view, Turker (2009) incorporated physical factors into the conceptualisation of EC-CSR defining it as 'activities which are directly related with the physical and psychological working environment of employees' ( $p$. 192). While the definition, does focus upon the specific types of internal CSR activities which could engender a positive physical and psychological working environment for employees, it is nevertheless, implied that a quality work environment devoid of workplace hazards could provide for employees' physical needs (Csiernik,2014). Moreover, employees' psychological needs could be addressed through practices such as work-life balance, job security, and empowerment, amongst others. In relation to the latter, Bauman and Skitka (2012) draw from micro-level psychological perspective to define EC-CSR as 'a means through which companies can address several of employees' needs, enhance their overall well-being, and strengthen their relationship with their organisation' (p. 75). They further posited that an employee relationship with the organisation, can be influenced by adopting internal CSR practices which could fulfil four basic psychological needs (i.e., security, selfesteem, sense of belongingness, and work meaningfulness), thereby, enabling organisations to have a positive complement to formal employment contracts.

Drawing on extant definitions evidenced above, we define EC-CSR as 'organisational practices aimed at providing for employees' social expectations with the purpose of creating quality of working life and workplace harmony'.

Having defined EC-CSR, we now focus upon examining the contextual implications for EC-CSR.

\section{EC-CSR and Context Specificity}

EC-CSR reiterates the need for organisations to make strategic allocations aimed at fulfilling employment-focused (e.g. workplace wellbeing) or extraneous (e.g. family and personal wellbeing) expectations of their workforce. In doing so, it is also imperative that organisations acknowledge the potential influences of context-specific factors upon employees' expectations. For instance, the African community life could have implications for employees' social expectations, permeating those expectations which are both formal and informal in nature.

Nevertheless, these informal employees' social expectations are largely underemphasised in western contexts (Matten and Moon 2008). For example, even though western-oriented EC-CSR practices, such as work-life balance does enable employees to achieve a balanced work and personal life (Delecta 2011), there are no indications that these practices acknowledges the socio-cultural priorities of non-westerners, such as indigenous African workers. Thus, we surmise that the socio-cultural prioirities of western organisations with regard to EC-CSR, might be different from those of their African contemporaries in view of the specificities of the African context. 
African specificities are not confined to socio-economic dimensions such as, poverty and informality, but as examined at the outset of this paper, they also include, the historico-political contextual dimensions, such as tribal identity and colonisation (Rivera-Santos et al. 2015).These dimensions are likely to influence employment relationships in Africa, thus offering opportunities for the advancement of Afrocentric factors within the EC-CSR discourse. Poverty for instance could influence the kind of social support employees expect from their employer and would in turn, determine the nature of their reciprocal behaviour within the employment relationship. Informality could affect employees' dress sense (e.g., preference for native clothing as official dresscode rather than the formal western dresscode). Informality could also affect employees' perception of the employment contract as they might overlook critical elements of the contract given that they are accustomed to communal informalities. Furthermore, tribal exigencies and differing worldviews, such as ubuntu could enlighten our understanding of how informal institutions influence individual decisions within the employment relationship.

Thus, while it could be argued that certain fundamentals of EC-CSR remain the same, the associated issues vary in nature and importance across industries and geographical locations (Atuguba and Dowuona-Hammond 2006). Hence, it is reasonable to surmise that organisations stand a better chance of fulfilling their employees' social expectations and potentially engendering workplace harmony if they are cognisant of prevalent religious, historical and cultural contexts of work while formulating their EC-CSR policies. Clearly, EC-CSR is a localised and socially embedded concept and as such the prevailing ideas, perceptions, and issues together with the modes of practicing it should conform to the dictates of the socio-economic [or socio-cultural] environment (Amaeshi et al. 2006).

Based upon the preceding arguments, and acknowledging the dominance of conventional (western) literature in ECCSR, we argue for the 'need to better understand the opportunities of Africa as a context for Africa-bound, Africaspecific, and universal research not only in areas related to business and society issues but also for the broader management literature' (Kolk and Rivera-Santos 2018, p. 428).

In the subsequent sections of this paper, we offer relevant propositions to justify the four aims of this paper. Figure 1 provides a graphic representation of the Afrocentric ECCSR and social exchange model proposed in this regard.

Proposition 1 Afrocentric exigencies play a critical role in shaping employees' psychological contract (i.e. employees' expectations) and organisational EC-CSR practices for fulfilling them.
Collectively, the psychological contract and EC-CSR revolve around employees' expectations of the organisation and the organisational practices aimed at fulfilling employees' expectations (see Luu 2016; O'Donohue and Nelson 2009). Thus, a deeper understanding of the psychological contract could help organisations in developing suitable EC-CSR strategies for fulfilling employees' social expectations. In this regard, the psychological contract is a prominent framework for understanding the perceived nature of employee-organisational relationship and its resultant implications upon employee attitudes and behaviours such as affective commitment and employee turnover intentions (Coyle-Shapiro and Conway 2005a; Coyle-Shapiro et al. 2019; Giannikis and Nikandrou 2013).

A psychological contract reflects 'an individual's beliefs regarding the terms and conditions of a reciprocal exchange agreement between that focal person and another party' (Rousseau 1989, p. 123). For instance, employees could perceive that it is their employer's responsibility to proactively address their concerns regarding employment stability, training, compensation, skills development (Bauman and Skitka 2012), and working conditions (Aguilera et al. 2007). These beliefs then, inform employees' social expectations of the organisation (e.g. EC-CSR) and their reciprocal obligations (e.g. commitment) to the organisation. While employees might be keen about gaining fulfilment for their expectations, conversely, organisations might be ignorant of them (Lucero and Allen 1994; Rousseau 1989; Shore and Tetrick 1994) as these expectations could be supplementary to their formal employment contract (Rousseau 2000).

Typologically, psychological contracts are transactional and relational in nature (Rousseau 1995). Transactional contracts are short-term economic exchanges characterised by explicit terms and conditions (Conway and Briner 2005; Morrison and Robinson 1997; Taylor et al. 2006), reflective of Behrend's (1957) bargain principle, 'a fair day's work for a fair day's pay!' (Rousseau and Wade-Benzoni 1994). In contrast, relational contracts permeate the personal and work life of employees (Coyle-Shapiro and Parzefall 2008), involving an emotional investment nurtured by promises, agreement trust, respect, and loyalty (Conway and Briner 2005) and a high level of tolerance (Morrison and Robinson 1997). The impact of relational contracts on employees exceed that of transactional contracts, in that employees with fulfilled relational contracts are more satisfied with their job and are unlikely to think about leaving their jobs (Raja and Johns 2010). However, employees who experience a breach of a transactional contract tend to exhibit lower job satisfaction, eventually reducing their affective organisational commitment (Raja et al. 2004).

While literature does not suggest that one type of psychological contract is superior to the other, it is fair to say that the nature of the contract depends on the employees' 
disposition, and the kind of resources that the employee and the organisation are willing to exchange. That said, effective management of relational contracts could be a corporate risk reduction strategy, especially in labour restive sectors in Africa such as the Nigerian oil industry (Fabamise 2018), and the South-African mining industry (Smith 2013), in that such an act could lessen employees' adverse reactions in the event of a formal breach of contract by the organisation (Dulac et al. 2008). In other words, instead of reacting negatively to a formal breach of contract, employees whose relational contracts are being fulfilled could give the organisation the benefit of the doubt (Rousseau 2000). Thus, given its dynamic nature, relational contracts tend to serve as a substitute for formal contracts that specify the traditional obligations of employees and employers engaging in fixed long-term employment (Voegtlin and Greenwood 2016).

Furthermore, the relational psychological contract interrelates closely with EC-CSR because both constructs subscribe to the notion that employees will positively reciprocate organisational practices such as, training and career development (Al-bdour et al. 2010; Barrena-Martínez et al. 2017; Brammer et al. 2007; Lee and Bruvold 2003; Mory et al. 2016), favourable working conditions (Conway and Briner 2005), management of employment relations (Hofman and Newman 2014; Mory et al. 2016), communication, transparency and social dialogue (Thang and Fassin 2017), diversity and equal opportunities (Al-bdour et al. 2010; Mory et al. 2016), fair renumeration and social benefits (Hofman and Newman 2014), prevention of health and safety at work (Al-bdour et al. 2010; Thang and Fassin 2017), and work-family balance (Al-bdour et al. 2010; Hofman and Newman 2014).

Nevertheless, while the psychological contract is a universal construct, the socio-cultural context of employees could influence what they expect of the organisation (Linde 2015). However, there are indications that African-based organisations accord little regard for indigenous influences on psychological contract, as they have mostly conformed to practices that emerged from Western organisational theories. For instance, individualism is emphasised in the western conceptions of the psychological contract-i.e. it is assumed that the individual can be understood as a separate being from others (Akbar 1984). This conception of individuality deemphasises other parties (e.g. family members, community members, and friends). Furthermore, the individualistic conception of a human's personality contradicts, the ubuntu Afrocentric philosophy which emphasises the need to cater for employees' personal wellbeing as well as those of their extended families (Mangaliso 2001; Khomba 2011). The ubuntu essence suggests that the social expectations of Afrocentric employees may include several non-contractual elements such as family and personal needs. While it can be argued that conventional (western) work-life balance practices provide for family needs (see Houston 2005), it places little emphasis on how the organisation could accommodate employees' family needs (e.g. healthcare, workplace childcare requirements) within their EC-CSR policy.

In terms of healthcare for instance, Wike and Simmons (2015) suggests that healthcare is a key priority in Sub-Saharan Africa. Clearly, $85 \%$ of the employees in the region value healthcare benefits from their companies more than other benefits-such as bonuses and retirement benefits (Consultancy. Africa 2018). Within Nigeria, for instance, the Formal Sector Social Health Insurance Programme (FSSHIP) of the National Health Insurance Scheme provides a system in which the health costs of employees are transferred to designated Health Maintenance Organisations (HMOs). However, employees rarely have access to basic medical care due to the poor state of medical infrastructure across the country (Welcome 2011). As such, employees' psychological contract in the African context would potentially be positioned towards an expectation of organisational support in the areas of medical care, not only for their personal self but for their immediate family as well.

Further influences upon the psychological contract can be seen in relation to employee expectations with regard to leadership, teamwork and collegiality. In terms of leadership, African indigenous leadership, due to its collective norms, strives to elicit opinions across the board. If disagreement ensues on an issue, the leadership would listen to all arguments until a unanimous decision has been reached (Chazan 1993; Gyekye 1992). In consonance with this practice, An Afrocentric workforce may in certain instances aim to participate in organisational decision-making especially when there is a conflict to resolve. Unlike Western rationality, Afrocentric decision-making process strives to preserve harmony by ensuring that a consensus has been reached before a decision is made (Mangaliso 2001).

Acknowledging the potential for ubuntu philosophy to be leveraged to foster team work and collaboration (see Nelson and Lundin 2010), as well as employee learning (Mbigi and Maree 2005), and leadership development (Ngunjiri 2016), the African workforce might be desirous of nurturing a collegial relationship with work colleagues to actualise their developmental priorities. In other words, workplace collaborations and teamwork could help employees to acquire professional skills informally via collegiate knowledge exchange platforms (Barrena-Martínez et al. 2017). However, such collegiality requires effective interpersonal communication, specifically face-to-face communication; which can enhance harmony in the workplace (Schiele 2000; Warfield-Coppock 1995)

By and large, our discussion above corroborates the contention that socio-cultural attributes affect individual interpretations of the psychological contract at work (Rousseau 1995; Raja et al. 2004). We specifically elaborate on 
how family considerations, national healthcare deficits and collective decision-making norms could influence psychological contracts or employees' expectations of EC-CSR. Even though the psychological contract has been studied across cultures, including collectivist and individualistic cultures (Schwartz and Sagiv 1995; Thomas et al. 2010), there is little reference on how it manifests in the African context. Going forward, we propose that Afrocentric factors play a crucial role in shaping the psychological contract and the reciprocal EC-CSR practices of organisations (see P1 above).

Proposition 2 (a) Fulfilment of Afrocentric relational psychological contract (i.e. employees' expectations regarding EC-CSR) can engender perceived organisational support.

Relational psychological contracts, EC-CSR and perceived organisational support (POS) are distinct constructs, yet they have functional interactions. While relational psychological contracts revolve around employees' schema about the obligations which exist between them and the organisation (Rousseau 1989, 1995), EC-CSR focuses on the practices aimed at fulfilling relational psychological contracts (Grimmer and Oddy 2007; Luu 2016; Mirvis 2012). The POS on the other hand reflects employees' perception of the extent to which the organisation values their contributions and cares about their well-being (Rhoades and Eisenberger 2002). In other words, POS explains employees' perception of the fulfilment of their social expectations. Despite the distinctive nature of these three constructs, they are all entrenched in the social exchange tradition which suggests that the relationship between the employees and the organisation is pivoted by an exchange of employee commitment for benefits such as social support and work recognition (Blau 1964; Gouldner 1960; Rhoades and Eisenberger 2002).

Conventional literature also suggests that a range of EC-CSR practices can influence POS (Glavas and Kelley 2014). Beyond that however, POS is also influenced by the socio-cultural values prevalent in a particular country (Gyekye and Salminen 2009). Apparently, we have leveraged Proposition 1 to expound on how Afrocentric socio-cultural values could influence psychological contracts (e.g. Thomas et al. 2010), and associative ECCSR practices of organisations. Along a similar vein, we propose that the fulfilment of the Afrocentric relational contract, specifically, 'a sense of community and respect for status, age and experience' could substantially influence perceived organisational support of employees in the African context. Justifiably, African values advocate the need for people to have a sense of belonging to a larger community or neighbourhood (Mangaliso 2001). Rather than conforming to the individualistic orientation of the western world, Afrocentric employees might be more disposed to working in an environment that espouses a sense of community to the extent that the workplace will be like 'a home away from home'. Communality at work creates a sense of belongingness, and simultaneously encourages employees to establish non-task related relationships and hence improves employee effectiveness and decreases their hostility towards the organisation (ibid.). When communality is thus promoted at the workplace, it is anticipated that employees would naturally see their colleagues as members of their extended family with whom they collaborate to achieve organisational objectives. Indeed, the affective commitment of employees to the organisation is exhibited when employees attain a sense of belongingness; a feeling that they are part of a big family (Stephens 2016). In view of the above, we surmise that Afrocentric employees would develop a perception of organisational support (POS) if the organisation encourages them to see themselves as one side of a coin and their colleagues as the other side. In other words, promoting community values at work can engender POS in the African workplace.

Furthermore, African people treasure respect for status and experience (Mangaliso 2001). While those in superior positions are usually highly educated and entitled to privileges and amenities, the subordinate workforce has little or no access to workplace amenities (Ridgeway 2013; Sheets and Braver 1999). Seniority in terms of work experience, and academic achievement is thus acknowledged and highly respected in Africa (Mangaliso 2001). The relatively higher educated, top management exercise judicial influence and authority in both work and non-work contexts (ibid.) in Africa. The power differentials accompanying status and experience enables employees in this category to perceive that their job assignment is stressfree (Gyekye and Salminen 2009) as they have greater work autonomy and less exposure to hazards and risks (Gyekye 2006). In line with the above discussion, we further surmise that African employees in higher-level positions value respect for status, and in turn, organisational actions related to respect for this value would engender their perceived organisational support (Mangaliso 2001).

Coyle-Shapiro and Conway (2005b) focuses more specifically, on the interrelationship between the fulfilment of the 'conventional' psychological contract and POS. While this interrelationship is incontrovertible, we extend our 'psychological contract vis-à-vis the socio-cultural' thesis in Proposition 1 to surmise that the African people could be susceptible to socio-cultural influences while creating organisational support perceptions; lending credence to Yoon and Kim's (1999) findings within the Korean's context. Our argument is further consolidated by Gyekye and Salminen's (2009) contention that seniority in terms 
of work experience and status could influence perceived organisational support.

Leveraging these thoughts, we propose (see P2-a) that the fulfilment of Afrocentric relational psychological contract can engender perceived organisational support.

\section{Proposition 2 (b) Breach of Afrocentric relational psycho-} logical contract can engender perceived employee cynicism.

While we can acknowledge that POS explains employee perception as to the degree to which an organisation values their contributions and cares about their well-being (Eisenberger et al. 1986), POS itself could engender either positive or negative outcomes. Literature has mainly focused on how POS serves as a cognitive channel for positive employee reciprocity in employment relations (Rhoades and Eisenberger 2002), neglecting the reality that employees could also reciprocate negatively where they perceive a dearth of organisational support. Hence, we are effectively constrained from having a grasp of the mental schema that employees typically develop when their expectations of EC-CSR are breached. As such, we posit that a deeper knowledge of employees' differential perceptions of organisational support is long-overdue as it could further enhance our understanding of the cognitive reasoning which evokes negative reciprocities in employment relationships.

In this regard, employee cynicism is defined as "a negative attitude towards one's employing organisation, comprising of three dimensions: (a) a belief that the organisation lacks integrity; (b) negative affect towards the organisation; and (c) tendencies to disparaging and critical behaviours towards the organisation that are consistent with these beliefs and affect' (Dean et al. 1998, p. 345). Cynicism therefore revolves around beliefs, affective and behavioural traits which are all rooted in attitudinal theory (Hilgard 1980). Research suggests that a breach of the psychological contract can lead to employee cynicism (Andersson and Bateman 1997) which would subsequently influence regressive employee outcomes such as job dissatisfaction, organisational detachment (Abraham 2000), reduced in-role performance and increased absenteeism (Johnson and O'LearyKelly 2003).

The cynical employee outcomes noted above can be induced by a number of factors which are also evident in the African work context. Firstly, employee cynicism could be caused by poor work environments and inequitable work practices (Boverie and Kroth 2001). Unsurprisingly, the oil sector's labour union in Nigeria are renowned for highlighting poor working conditions (IndustriALL Global Union 2018), and other inequitable employment practices such as the preference for expartriate workers rather than qualifed indigenous workers (Aye 2017; Fajana 2005). Similarly, South-African mining workers usually resort to violent work disruptions due to their dissatisfaction with their pay and working conditions (Elbra 2017). Secondly, employee cynicism could also be a result of limitations imposed upon employee participation in decision-making processes (Cartwright and Holmes 2006), leading to a protracted failure of management resulting in employee mistrust (Fleming 2005; Andersson and Bateman 1997). The outcomes of such cynicism can again be seen in the Nigerian oil sector, where workers agitate to increase their participation in corporate decision-making processes (Fajana 2005), due to the pervasive adversarial employee-organisational relationship extant in the sector (Chidi et al. 2011).

Conclusively, despite the notion that 'the underlying tenet of Afrocentric leadership is collectivism' (Shonhiwa 2006, p. 41), employees are still prone to adopt negative outcomes resulting from employee cynicism towards their organisation. This is due to the widening gap between employees and their management in some Africa organisations, cognisant of power distance (e.g. Hofstede 2002). In effect, despite the collectivist inclinations of African cultures, power resides in the hands of management who sometimes create a relational distance between their subordinates and themselves, thus, breaching a subordinate's relational psychological contract, resulting in cynical employee outomes.

Proposition 3 In line with the rational norm of reciprocity, the fulfilment of employees' social expectations will positively influence employee-organisational commitment and other work-related outcomes.

Although the psychological contract (as discussed in Propositions 1 and 2) explains what employees could typically expect of the organisation, it does not capture the norm of reciprocity embedded within employment relationships. In fact, reciprocity dynamics in employment relationships is explained through the social exchange theory (Blau 1964; Gouldner 1960). The social exchange theory posits that individuals give resources or help to others with the expectation that their actions will be duly rewarded in kind (Blau 1964; Homans 1974). In effect, an individual who had received support is likely to reciprocate the benefactor with high trust and emotional engagement (Blau 1964), in the form of loyalty and commitment. This form of exchange consolidates the employment relationship (Coyle-Shapiro and Kessler 2002; Gouldner 1960). Social exchange could be shaped by promises made by the organisation to the employee or by what the employee expects of the organisation (Chaudhry and Song 2014). Irrespective of the direction within which social exchange takes place, the common assumption is that promises give rise to expectations (Ederer and Stremitzer 2017).

Social exchange is further driven by relational (socioemotional) considerations (Shore et al. 2006), thus, resulting 
in implicit obligations subject to the discretion of the parties involved (Molm 2010). Given its implicit nature, social exchange requires trust (Emerson 1981), which acts as an enabler of social exchange, inspiring the employee to enter into a relationship with the organisation (Cropanzano and Mitchell 2005). The nexus between the fulfilment of employees' expectations regarding EC-CSR and the evolving attitudinal reciprocity is reinforced by the belief that employees would reciprocate organisational support through their continuous loyalty and commitment to the organisation (Coyle-Shapiro and Shore 2007; Eisenberger et al. 2016). Indeed, Perceived Organisational Support (POS) can potentially mediate the exchange relationship between EC-CSR and employees' attitudinal reciprocity (i.e. EOC) (Glavas and Kelley 2014). We acknowledge this nexus in our proposed model (see Fig. 1).

Arguably, employees would show more gratitude for discretionary organisational support than those necessitated by legal regulations or by labour pressure (Eisenberger et al. 2001). In this perspective, EC-CSR itself is perceived as a discretionary practice aimed at supporting employees with an inherent expectation that the beneficiaries (i.e. employees) would reciprocate the benefactor's (i.e. employer's) prosocial act. Founded upon this thought, EC-CSR scholars (e.g. Al-bdour et al. 2010; Mory et al. 2016) have adopted social exchange theory to explain employees' attitudinal reaction to EC-CSR.

In line with the above arguments, our third proposition (P3) suggests that the fulfilment of employees' social expectations (i.e., relational psychological contract) will influence employee-organisational commitment (EOC), which will subsequently influence other work-related outcomes such as skills retention and turnover costs in a positive manner.

Proposition 4 In line with the rational norm of reciprocity, breach of employees' expectations regarding EC-CSR will negatively influence employee-organisational commitment and other work-related outcomes.

Similar to our discussion for Proposition 3, the social exchange theory (Blau 1964) further provides the theoretical foundation for most of the studies on a breach of social expectations at work (Zhao et al. 2007). In effect, when employees feel that their organisations have breached an expectation, they are more likely to feel angered, betrayed and undervalued, and will possibly reciprocate by withdrawing their trust and commitment to the organisation (e.g. $\mathrm{Ng}$ et al. 2010). Empirically, it has been established that a breach of the psychological contract impacts negatively on affective organisational commitment (e.g. Arain et al. 2012), comprising of an individual's belief in their organisation's goals and their willingness to contribute consistently to the organisation (Allen and Meyer 1991).
In this regard, our fourth proposition (P4) argues that the breach of employees' social expectations will result in employee detachment, and subsequently engender labour coalitions, employee hostility and industrial actions (Blau 1964). Accordingly, empirical evidence suggests a negative link between the breach of employees' social expectations and work-related outcomes, particularly employee-organisational commitment (Raja et al. 2004; Restubog et al. 2006), job satisfaction (Orvis et al. 2008) employee turnover (Lum et al. 1998), and organisational citizenship behaviours (Robinson and Morrison 1995).

Nonetheless, employees' reaction to a breach of their social expectations' vary across countries. However, there is scarce literature in this area. In the section below, we expound on the nature of positive recipority that might evolve from an African context even in the face of a breach of expectations in the workplace.

\section{Afrocentric Reciprocity: Does It Negate the Rational Norm of Social Exchange?}

At the epistemological level, reciprocity exhibits some complexities with regard to its identification as an explanatory concept or a behavioural norm. Even if it is identified as an explanatory concept, uncertainties remain with regard to it being representative of employees' experiences (Lemarchand 1989). Nevertheless, as an explanatory concept, reciprocity may advance a view of social exchange which is not influenced by inducement by either of the parties involved in the exchange (ibid.). In effect, it may occur as a response to a fear of retaliation (e.g. disengagement or job loss) rather than as a response to actual organisational support (ECCSR). For instance, everyone on the Zimbabwean Gwenbe Tonga's homestead had a premonition that since no one knows whether the person who asks for help has the power to cause harm, each request in the community should be treated as if it came from someone who might be dangerous (Colson 1974). As such, 'it seemed perfectly reasonable for them [i.e. the Tonga people] to accede to avoid possible retaliation' (ibid., p. 49). The Tonga's experience suggests that some Africans could exhibit positive reciprocity even when they are not accorded positive inducements, due to the fear of retaliation and obviously, indigenous influences. This argument is premised on the notion that some Africans reciprocate due to cultural or psychological mandates than self-interest. Hence, Afrocentric reciprocity is perceived as an organising force of society (Mauss 1969), motivated by an unconscious identification with indigenous norms and values as well as by the need to develop a conscious coping strategy in the form of adaptive behaviour by employees (Jameson 2010). 
Another issue evolves from concerns regarding the level at which reciprocity unfolds. For instance, can reciprocity be treated as a 'culturally-induced moral obligation'? (Blau 1964), or as a 'rational calculus of costs and benefits'? (Lemarchand 1989; Mauss 1969). One can argue that the rational view of reciprocity may be disregarded in societies in which the culturally-induced moral obligations remain a crucial phenomenon (Hydén 1980). As such there are indications that the indigenous values of some Africans correspond with Malinowski's (1922) thesis on folk beliefs where the people's stances on reciprocity suggests the manifestation of irrationalities.

Yet these stances are not being captured in conventional studies. For instance, no efforts have been made to investigate the reason as to why Nigerian states' civil servants continue to go to work despite not being paid for several months (see Akinpelu 2015). Is this 'selfless' commitment by employees? Or is it a form of employee commitment induced by the anticipated future benefits from remaining in the civil service? Or is employee commitment motivated by 'Tonga's fear of the unknown syndrome' - such as a fear of job termination? If the anticipated future benefits are not forthcoming, what is the theoretical or empirical basis for assuming that employees will not commit to the civil service in the future? In view of these prevailing complexities, it is pertinent to raise propositions that reflect the indigenous norms and values vis-a vis social exchange. While we are conscious that several possibilities are embedded in our preceding propositions (i.e., Propositions 1-4), we cannot uphold knowledge conservatism and limit our subscription to the rational exchange norm without acknowledging the influence of the indigenous mandate within reciprocity processes. Hence, we propose below that a breach of employees' social expectations can be reciprocated with employeeorganisational commitment in the African context. The 'esan reciprocity ideology' lends credence to this proposition.

Proposition 5 In line with esan reciprocity ideology, breach of employees' social expectations could be positively reciprocated.

We begin by acknowledging De Roek and Maon's (2018) thesis that individual contingencies such as socio-demographic characteristics and individuals' attitude towards ECCSR, reciprocity, and morality can play a crucial role in how employees perceive and react to EC-CSR initiatives. Beyond individual contingencies however, we hold that collective contingencies such as indigenous values or spirituality may influence how employees reciprocate the breach of their social expectations. Aptly, an Afrocentric ethical ideology referred to as esan can influence employees' reciprocity orientation in the workplace. For clarity, the word esan evolved from the Odu Ifa, and is roughly referred to as "cosmic justice' (Balogun 2013, p. 114), whereby 'justice [itself is perceived] as reciprocity' (Buchanan 1990, p. 227; Lister 2011). Interestingly, 'social cooperation based on reciprocity is the cornerstone of many theories of justice' (Hartley 2014, p. 409). As narrated by Elebuibon (2004), the word esan denotes 9 (nine) in Yoruba numerology and it simply mean 'it turns' or to do something alternately or in succession. Thus, 'to take turns' is lati sesan (to reciprocate). Hence, [e]san basically represents the principle of reciprocity and it connotes turning over, results and exchange (Fasola 2015). In this way, 'esan is that which a moral agent receives as a consequence of his/her moral deeds' (Balogun 2013, p. 114). Just as esan may be pleasant or otherwise dependent upon the agent's character (ibid.), rational reciprocity could take a positive path: you scratch my back, I'll scratch yours, or a negative path: an eye for an eye, a tooth for a tooth (Donlan 1998). The rational norm of reciprocity in a sense conforms with the parlance; whatever a man sows, he shall reap, as well as the Yoruba saying, rere ati ika, ikan ko ni gbe (good or bad, none shall be lost).

Despite the extant belief that neither 'good nor bad shall be lost', Yoruba ethics decries the intention to retaliate the bad inflicted upon a party by the other party (Balogun 2013). This is because negative reciprocity is detrimental and can lead to a downward spiral as each side punishes what it perceived to be negative acts by the other. In this regard the Yoruba ethical tradition suggests that it is of no use to reciprocate a bad deed with a bad deed. As noted in Oluwole (2017) 'se mi ki n se o, ki i jeki oran o tan', meaning, 'what you do to me, I do to you does not allow for the problem to be resolved swiftly' (p. 213). To avoid the detrimental consequences of negative reciprocity, Yoruba ethical tradition stresses the need to do good always: rere lo pe; ika kosunwon, meaning, moral goodness pays; wickedness is unpleasant (Balogun 2013).

So, rather than reciprocating bad deeds with bad deeds, Yoruba ideology prescribes that reciprocity should be left to Olodumare (God), ${ }^{2}$ the fair judge (Dopamu and Alana 2004). The thrust of this belief is that the good or bad done to others has a way of returning to the doer or their family. Hence, social exchanges are not motivated by self-seeking interests but rather long-term profitable consequences that transcends rational reasoning (Oke 1988). Being conscious of these, Yoruba people strive to uphold the ethical prescription for esan which decries negative reciprocity (Dopamu and Alana 2004). Interestingly, esan reciprocity ideology correlates with the Christian tenet: 'Do not take revenge, my

\footnotetext{
2 The name Olodumare, a Yoruba name for God carries the idea of 'One with whom man may enter into a covenant or communion in any place and at any time, one who is supreme, superlatively great, incomparable and unsurpassable in majesty, excellent in attributes, stable, unchanging, constant, reliable (Idowu 1962, p. 36).
} 
dear friends, but leave room for God's wrath, for it is written: It is mine to avenge; I will repay, says the Lord' (Bible Hub 2004-2019; New International Version—Romans, 12:19), as well as the Islam tenet which suggests that reconciliation is always preferable to retaliation: 'And the retribution for an evil act is an evil one like it, but whoever pardons and makes reconciliation-his reward is [due] from Allah. Indeed, He does not like wrongdoers'. (Corpus Quran 2009-2017, 42: 40). By and large, esan reciprocity ideology as well as the denominational tenets of Christianity and Islam on negative reciprocity subscribes to a common belief that bad deeds should not be reciprocated with bad deeds.

As much as we seek to caution that the esan reciprocity ideology and its perceived religious connotations may not necessarily apply to all Africans, there are indications the African people have a reasonably similar environment, social [and religious] influences, and lifestyle, hence they tend to exhibit unique attributes which distinguishes them from people in other parts of the world who have different experiences and environments (Awolalu 1976). For instance, Africans collectively perceive that hospitality and warmth is a distinctive marker of their identity. Africans also still tend to instinctively believe in transcendental cultural commonalities, ways of seeing and being that establish their uniqueness and distinguish themselves from the rest of humanity (Adesanmi 2012).

Based upon the preceding discussion we argue that the esan reciprocity ideology may not be peculiar to the Yoruba society but to other Africans in that it aligns with the tenets of the two predominant religious denominations in Africa (i.e., Christianity and Islam). Notably, Africa's various populations and individuals are mostly adherents of Christianity, Islam, and to a lesser extent several traditional African religions. In Christian or Islamic communities, religious beliefs are also sometimes characterised with syncretism with the beliefs and practices of traditional religions (Awolalu 1976; Shahadah 2017). Indeed, Awolalu (1976) suggests that 'when we speak of African traditional religion, we mean the indigenous religious beliefs and practices of the Africans. It is the religion which resulted from the sustaining faith held by the forebears of the present Africans, and which is being practiced today in various forms and various shades and intensities by a very large number of Africans, including individuals who claim to be Muslims or Christians' ( $p$. 1). Furthermore, religion exerts a significant influence upon the life of most Africans such that many colonialists referred to Africans as being: 'incurably religious' (Parrinder 1969, p. 235). This extreme religiosity of Africans has inspired some scholars to claim that there is a link between religion and morality in African ethics (Opoku 1978; Idowu 1962).

The question then is, should an employee whose rights have been breached by the employer reciprocate the employer in a negative manner? Just as the tenets of
Christianity and Islam decries negative reciprocity (see New International Version-Romans, 12:19; 1 Peter 3:9; and Quran 42:40), esan reciprocity ideology decries the same (Balogun 2013). This is because negative reciprocity is detrimental and can lead to a downward spiral as each side punishes what it perceives to be negative acts by the other (Elebuibon 2004). What this suggests is that an employee who subscribes to esan reciprocity ideology, and whose rights are being breached at work might choose to endure the breach rather than reciprocate in a negative manner. This form of 'tolerance in the workplace' could also be likened to the Yoruba ethical values that encourages womenfolk to endure the pains of 'men's misdemeanour' in the matrimonial home instead of resisting it (Ajibade 2014, p. 224). Rather than 'addressing the wrong attitudes and practices of wayward men, the women are admonished to employ patience and endurance to quench the flame of impending conflict' (ibid., p. 224). In line with this view, Yoruba ethical ideology advocates patience for all occasions, except when one is exposed to hazards (Ijatuyi-Morphé 2014). In furtherance of its ethical mandate, Yoruba also use synonyms such as calmness (pele pele), endurance (ifarada), inner strength or reflection (ogbon inu), contentment (ifokanbale) to describe the virtues of patience (ibid., p. 340). Nevertheless, patience in this context is never considered as a total resignation. As rightly noted in a Yoruba maxim: 'onisuru ni yi o j' ogun aye, [meaning] the patient shall inherit the world' (IjatuyiMorphé 2014, p. 340). Those who subscribe to these ethical beliefs are thus prone to exhibit their convictions in their employment relationships.

Just like the exercise of patience does not connote total resignation (ibid.), subscription to esan reciprocity ideology does not imply that one should not expect payback, at least for a good deed. For instance, many social interactions in traditional African society were characterised by positive reciprocity. The blacksmith or ironsmith would exchange their products/tools with containers made by pottery workers (Shizha 2016). This form of social exchange is basically fundamental to the continuation of industrial skills that were developed amongst groups within communities (ibid.). Yet, African blacksmiths' kind of reciprocity is motivated primarily by social rather than economic rationality or selfcentredness (Sundström 1974). In fact, 'in pre-colonial African society, reciprocity strengthened the norms that called for collective actions, and those that operated at the level of self-interest were ridiculed and severely sanctioned' (Shizha 2016, p. 56). This suggests that the Afrocentric social exchange orientation is inherently altruistic and relational.

Interestingly, Sahlins (2017) mirrors the exchange attributes of Africans by explicating how the exchange of objects between groups consolidates social relationships. It was also discovered that the Afrocentric social exchange revolves around affective obligations to give, to receive and 
most importantly, to reciprocate within groups and not only amongst individuals as evident in the rational exchange orientation (ibid.). The Afrocentric social exchange landscape is also evident in the patron-client bond, rotating credit associations, self-help schemes, parochial corruption (Lemarchand 1989), and the African Osusu self-financing system (Lahai 2012). Consequently, we see the Afrocentric dimension to social exchange as a natural phenomenon that generates not just wealth, but social bonds between individuals and communities or organisations (Lemarchand 1989).

This form of kinship bond is also further corroborated by the overtones of Afrocentric ethical philosophy referred to as ubuntu (Nussbaum 2003; Metz 2007). The ethical profundity of ubuntu is largely ascribed to its theoretical vigour to foster harmonious, caring, humane and affirming relationships amongst individuals (ibid.), as well as its potency to make up for the limitations of 'individual philosophical systems' upon which most theories of management were established (Lutz 2009, p. 313). Further, perceived Afrocentric exchange tradition as exemplified in esan ethical ideology, the African Blacksmiths' exchange tradition, African self-help financing such as osusu reinforces the ubuntu relational aphorism: 'I am, because we are; and since we are, therefore I am' (Mbiti 1989, p. 106). These Afrocentric exchange traditions are so unique for the fact that they revolve around the idea that 'human beings are radically interdependent, and that this interdependence entails a morally normative pressure towards generosity, hospitality, friendliness, compassion, forgiveness, reconciliation, consensus, and positive group identification' (Van Niekerk 2013, p. 5).

Aside from the aforementioned, the uniqueness of the Afrocentric exchange tradition is further strengthened by the assumption that the good of the community is seen as fundamental and recognising the role of community is essential in respecting individual persons (Shutte 2008). It is therefore not strange to see that the Afrocentric social exchange is driven by collective reciprocity (Shizha 2016). These virtues have significant relevance for sustaining a relationship such as those that develop between employees and their employers. Indeed, collectivism play a significant role in shaping employees' commitment to the organisation (Hofman and Newman 2014). Similarly, it is assumed that [regardless of their unpleasant experiences at work] those who subscribe to collective values would treat employment relationships akin to a kinship relationship; which is characterised by loyalty and selfless care for one another (Hofstede 1984; Redpath and Nielsen 1997).

However, it is also quite likely that African employees accord positive reciprocity towards their organisations to avoid sanctions (see Irwin 2009), due to their collectivist orientation (Triandis 2001). The employer-employee interactions in collectivist societies consist of multiple relationships (i.e., family, work, friendship) (Irwin 2009). This multiplicity of relations could potentially offer managers ample opportunities to monitor subordinates and sanction negative reciprocity, disregarding those organisational factors which could have induced such reciprocity. Hence, the monitoring and sanctioning systems characterising a collectivist society engenders localised institutional trust. Simply, 'localised institutional trust refers to the belief that a system of monitoring and sanctioning existing within the local group induces trustworthy behaviour' (Irwin 2009, p. 173). Due to localised institutional trust, employees are prone to exhibit trustworthiness and prosocial behaviours (positive reciprocity) despite the unpleasant experiences they are facing in employment relationship.

Nevertheless, we surmise that instead of subjecting employees to monitoring and sanctions to subjugate them, organisations should see employees as a 'relation holder' whose welfare should be adequately protected. The DeRoeck and Maon's advancement of 'relation holder theory' as a heuristic for organisational decision-making further strengthens the relevance of African ethical ideologies, such as ubuntu and esan reciprocity ideology for shaping social harmony in workplace relationships.

We firmly believe that the African workplace governance model should substantially consolidate indigenous values as this could ultimately engender a win-win relationship for organisations and its 'relation holders' (specifically, employees). Besides, the consolidation of indigenous values at the African workplace would make both the employee and the employer appreciate the spiritual essence of work relationships rather that seeing such relationships as one that is bounded by rational self-interest. Unfortunately, such reasoning is rarely detected or apprehended in the conventional employee-organisation relationship literature.

\section{Discussion}

At the very outset of this paper, we stated our objectives. We now discuss how our conceptualisation of the interactions between and amongst the different conceptual dimensions depicted in our framework (see Fig. 1), enabled us to achieve these objectives.

In relation to our first objective, we argued through our first proposition, that both the relational psychological contract of employees and EC-CSR, are susceptible to sociocultural exigencies such as the ubuntu Afrocentric philosophy, which for instance suggests that employees may expect the organisation to provide for family needs, including healthcare, and funeral arrangements (Khomba 2011). More compelling is the urgency of employees' quest for healthcare in the African region to the extent that $85 \%$ of the employees in the region value healthcare benefits from their companies more than other benefits (Consultancy. Africa 2018). 
The poor state of medical infrastructure in some African regions further accounts for this trend (Welcome 2011). We further demonstrated that the collective nature of Africans (Hofstede 2009) could also influence psychological contracts and associative EC-CSR in terms of employees' quest to participate in organisational decision-making, lending credence to the implications of ubuntu for team work and collaboration (Nelson and Lundin 2010), as well as employee learning (Mbigi and Maree 2005), and leadership development (Ngunjiri 2016).

Second, we juxtaposed conventional conceptualisations of perceived organisational support with Afrocentric intricacies. In addressing this objective, we explained how conventional literature tends to ignore the role of socio-cultural factors in this process of fulfilment of relational psychological contracts through EC-CSR practices. We thus extended our proposition that the fulfilment of Afrocentric relational psychological contract, specifically, by 'creating a sense of community and respect for status and experience' could substantially influence perceived organisational support in the African context. This argument is further consolidated by the contention that seniority in terms of experience and status (Gyekye and Salminen 2009) could influence perceived organisational support. The contention that perceived organisational support in the African context could be engendered by 'sense of community belonging' lends credence to some views suggesting that collectivism is fundamental to African cultures (Belgrave and Allison 2018; Hofstede 1994, 2002). Besides, the belief that 'respect for status and experience' could engender POS affirms the traditional values being accorded to seniority, as well as the prevalence of asymmetrical relationships, which are peculiar to Afrocentric collectivism and high power distance (Bochner and Hesketh 1994; Gyekye and Salminen 2005; Hofstede 1994, 2002). In the opposite vein, we juxtaposed conventional conceptualisations of perceived employee cynicism with Afrocentric intricacies to suggest that the breach of relational contracts can instigate employee cynicism (Andersson 1996), which subsequently result in a number of negative behaviour/ attitudes (see Abraham 2000; Johnson and O'Leary-Kelly 2003). Yet there are peculiar triggers of employee cynicism, unique to the African context but are less visible in conventional literature. For instance, we affirmed that employee cynicism could be caused by poor work environments and inequitable work practices (Boverie and Kroth 2001) such as those seen in the Nigerian oil sector (Aye 2017, Fajana 2005), the South-African mining sector (Elbra 2017).

In view of the argument that commitment of employees to the organisation is contingent upon the nature of social inducements that employees derive from the organisation (Wayne et al. 1997), and the arguments suggesting that social inducements (i.e. EC-CSR) can influence employee commitment (Mory et al. 2016), our third objective drew upon the rational thesis of Blau's (1964) social exchange theory and the norm of reciprocity (Homans 1961) to suggest that fulfilling employees' expectations of EC-CSR will have a positive influence on employee-organisational commitment (i.e., proposition 3).We further drew on the social exchange theory and the norm of reciprocity to suggest that a 'breach' of employees' expectations of EC-CSR will negatively influence employee-organisational commitment (i.e., proposition 4). We however suggest that employees that subscribe to Afrocentric ethical ideology (i.e., esan reciprocity ideology) could commit to their employers even when they are not socially induced by the employer to do so. In line with this thought, we devoted to our final objective to examining how Blau's social exchange rationality contrasts with the esan reciprocity ideology (i.e., proposition 5). In proposition 5 , we affirmed that collective contingencies such as indigenous values or spirituality may influence how employees reciprocate the breach of their social expectations. Hence, we proposed that an Afrocentric ethical ideology referred to as esan can influence employees' reciprocity orientation in the workplace. We argued that even though esan ethical ideology subscribes to the 'tit for tat' norm of reciprocity, it decries the intention to retaliate the bad inflicted upon a party by the other party (Balogun 2013) because negative reciprocity is detrimental and can lead to a downward spiral as each side punishes what it perceived to be negative acts by the other (see Oluwole 2017, p. 213).

Furthermore, in some instances when employees' expectations are breached by the organisation and labour disputes occur (as demonstrated in Proposition 4), employees that subscribe to Afrocentric ethics could refrain from participating in prolonged labour disputes due to their indigenous ethical stance which is imbued with reconciliatory spirit. As noted in a Yoruba proverb, 'kò seni tii rinu ti kii bi, bee ni omo ale eniyan ni a n be ti kii gba' (there is no one that cannot be offended, but it is only a bastard person that doesn't agree to pleas) (Ajibade 2014, p. 229). In other words, African ethics suggests that a person whose rights have been breached should not dwell so much on the quest to claim those rights but should seek reconciliation and summon a forgiving spirit. This reconciliatory stance is also reinforced in the ubuntu philosophy which suggests that 'human beings are radically interdependent, and that this interdependence entails a morally normative pressure towards [...] forgiveness, [and] reconciliation (Van Niekerk 2013, p. 5). The efficacy of the alajobi (consanguinity or common progeny) conflict management mechanism of the Yoruba people in West Africa (see Ajibade 2014), and the ubuntu lessons in reconciliation (see Murithi 2009) further attest to the forgiving stance of Africans and the reconciliatory vigour of indigenous conflict resolution mechanisms.

In the above sense, our framework (see Fig. 1) suggests the need to rethink the rational thesis of the social exchange 
by acknowledging that some employees, specifically native Africans, could exhibit peculiar or irrational stances while reciprocating organisational support or neglect. This peculiar strand of reciprocity referred to as esan reciprocity ideology, conditions employees to positively contribute to the organisation despite the breach of their expectations of the organisation. We firstly visualise esan ideology from the perspective of indigenous spirituality and subsequently expound on the implications of the ideology for the conventional employment relationship, specifically in terms of an organisation's disposition towards employees who might remain resolutely committed to the organisation despite a consistent breach of their expectations. Our caution here is that organisations should not always ascribe employee commitment to the organisation despite their unpleasant experiences therein to the normativity, continuity or affectivity thesis of the organisational commitment model (Allen and Meyer 1991; Meyer et al. 2002). Besides, employee commitment to the organisation should not also be ascribed solely to their docility, complacency, macro-economic misfortune and a lack of alternative job prospects.

Additionally, African management requires a management theory that conforms to its indigenous culture (Lutz 2009). In instances where such a theory is lacking, there will be either a disagreement between management theory and management practice or a disagreement between management practice and the manager's culture. Rather than resorting exclusively to Western models to resolve conflicts arising from the neglect of employees' expectations, there is a need to revisit indigenous mechanisms which was the bedrock of the harmonious relationship in Africa prior to Western colonisation. Although, we are not totally positive that an indigenous conflict resolution model alone will proffer solutions to workplace conflicts, it is still important to reflect on how some aspects of Africa's indigenous models can be integrated with Western models to effectively respond to workplace conflicts. This preference for restorative and reconciliatory conflict resolution mechanisms rather than the Western organisational justice model is similar to preference for harmony and participatory emphasis of ubuntu rather than a preference for 'rights, stakes, or freedom' emphasising a libertarian stakeholder theory (see Woermann and Engelbrecht 2019, p. 42). The promotion of indigenous ethics such as esan reciprocity ideology and the integration of indigenous traditions and western modernity to resolve conflicts in the African workplace can be achieved through interactive problem-solving workshops (e.g., Murithi 2008), and through brainstorming sessions between African scholars, corporate practitioners and custodians of indigenous values. Conclusively, we surmise that the adaptation of Western management theories to home-grown theories is exigent to engender social harmony in the Afrocentric workplace.
By and large, African ethical discourses are sparingly represented in the global ethical debate (Shutte 2008). Given the extent of this underrepresentation, African indigenous models on ethics may be constrained from being fully integrated with employment relation practices if context-specific models are not entrenched within the mainstream management literature. Additionally, we may not be able to avail ourselves of the ample benefits that African ethical models offer if corporate practitioners do not possess the native ingenuity to adapt and integrate these models into employment relations. Thus, there is an urgent need for managers in the Afrocentric work context (and beyond) to seek well-rounded indigenous knowledge and capacity development such that relevant managers can engender employment practices which integrate the indigenous norms of their employees.

\section{Conclusion}

In this paper, we drew upon the psychological contract and social exchange theories to suggest differing features surrounding employees' social expectations of the organisation as well as the reciprocities associated with the fulfilment and breach of these expectations. Accordingly, we suggested that employees' social expectations of the organisation are better addressed through EC-CSR, which has in recent times, become a recurrent topic of conversation in scholarly literature, the classroom, media, and the boardroom (De Roeck and Maon 2018). Based on an extant empirical review, four theoretical propositions (P1-P4) were initially advanced. Our subsequent proposition (P5) suggests that reciprocity in some African context could at times be spiritual and irrational due to the influence of indigenous norms and values. In our discussion, we suggest that relational crises that might arise from breach of social expectations, particularly in the African context, are better managed through indigenous conflict resolution mechanisms, which can be adapted to employee-organisational relationships. Specifically, reference was made to a Yoruba indigenous conflict resolution mechanism" such as alajobi (i.e. consanguinity or common progeny). The argument in this paper is that these indigenous mechanisms have implications for the employment relationship, hence they should not be ignored or perceived as primitive. Rather, managers across the board should appreciate these values and aim to nurture a deeper knowledge of the intricacies embedded within them.

Apparently, actors in the African employment context require an in-depth understanding of indigenous values. To this extent, there exist opportunities to empirically investigate the nature of reciprocity evolving from fulfilment and breach of employees' social expectations in African work contexts. To validate the veracity of our proposition on perceived Afrocentric reciprocity (i.e. esan reciprocity 
ideology), empirical studies could initiate scenarioized investigations to unravel how native Africans in the workplace (especially those currently working in organisations with robust EC-CSR practices) would reciprocate the neglect of their social expectations at the workplace. Additionally, empirical studies could also investigate the conciliation mechanisms that native Africans would prefer for resolving employment disputes/Ultimately, insights from these studies could contribute to the development of effective Afrocentric employment relations strategies.

Acknowledgements We are grateful for the critical comments of Prof. Jean-Pascal Gond and Dr. Ruth Yeoman on the preliminary version of this paper that was presented at the 3rd International Symposium on Meaningful Work at Vrije Universiteit Amsterdam in June 2018. We are also grateful to the three anonymous reviewers and session 2090 participants who provided constructive comments on another version of this paper that was presented at the 78th Annual Meeting of the Academy of Management, Chicago, U.S.A. held in August 2018.

\section{Compliance with Ethical Standards}

Conflict of interest We the authors, Oluseyi Aju and Eshani Beddewela declare that we have no conflict of interest.

Ethical Approval This article does not contain any studies with human participants performed by any of the authors.

Open Access This article is distributed under the terms of the Creative Commons Attribution 4.0 International License (http://creativeco mmons.org/licenses/by/4.0/), which permits unrestricted use, distribution, and reproduction in any medium, provided you give appropriate credit to the original author(s) and the source, provide a link to the Creative Commons license, and indicate if changes were made.

\section{References}

Abraham, R. (2000). Organizational cynicism: Bases and consequences. Genetic, Social, and General Psychology Monographs, 126(3), 269-292.

Adesanmi, P. (2012). You're not a country, Africa. A personal history of the African Present. Johannesburg: Penguin Global.

Aguilera, R., Rupp, D., Williams, C., \& Ganapathi, J. (2007). Putting the $\mathrm{S}$ back in corporate social responsibility: A multilevel theory of social change in organizations. Academy of Management Review, 32(3), 836-863.

Agulanna, C. (2010). Community and human wellbeing in an African culture. Trames: A Journal of the Humanities \& Social Sciences, 14(3), 282-297.

Ajibade, O. (2014). Sparks of Resistance, Flames of Change Orature in Reconciliation and Conflict Management among the Yorùbá. In A. Adebayo, et al. (Eds.), Indigenous conflict management strategies in West Africa: Beyond right and wrong (pp. 211-232). London: Lexington Books.

Akbar, N. (1984). Chains and images of psychological slavery. Jersey City: New Mind.

Akinola, A., \& Uzodike, U. (2017). Ubuntu and the Quest for Conflict Resolution in Africa. Journal of Black Studies, 49(2), 91-113.
Akinpelu, O. (2015, August 11). Unpaid wages: An abuse of labour rights. The Guardian Nigeria. Retrieved from https://guardian. ng/features/law/unpaid-wages-an-abuse-of-labour-rights/.

Akintoye, S. A. (2010). A history of the Yoruba people. Dakar: Amalion Publishing.

Al-bdour, A., Nasruddin, E., \& Lin, S. (2010). The relationship between internal corporate social responsibility and organizational commitment within the banking sector in Jordan. International Journal of Human and Social Sciences, 5(14), 932-951.

Alexander, P. (2016). Marikana Commission of Inquiry: From narratives towards history. Journal of Southern African Studies, 42(5), 815-839.

Allen, N., \& Meyer, J. (1991). The measurement and antecedents of affective, continuance and normative commitment to the organization. Journal of Occupational Psychology, 63(1), 1-18.

Amaeshi, K., Adi, B., Ogbechie, C., \& Amao, O. (2006). Corporate Social Responsibility in Nigeria: Western Mimicry or Indigenous Influences? The Journal of Corporate Citizenship, 24, 83-99.

Andersson, L. (1996). Employee cynicism: An examination using a contract violation framework. Human Relations, 49(11), $1395-1418$.

Andersson, L., \& Bateman, T. (1997). Cynicism in the workplace: Some causes and effects. Journal of Organizational Behavior, 18(5), 449-469.

Arain, G., Hameed, I., \& Farooq, O. (2012). Integrating workplace affect with psychological contract breach and employees' attitudes. Global Business and Organizational Excellence, 31(6), $50-62$.

Atuguba, R., \& Dowuona-Hammond, C. (2006). Corporate social responsibility in Ghana. A report submitted to FES-Foundation, Ghana. Retrieved from http://citeseerx.ist.psu.edu.

Awolalu, J. O. (1976). What is African traditional religion? Studies in Comparative Religion, 10(2), 1-10.

Aye, B. (2017). NUPENGASSAN: Combatting precarious work in the Nigerian Oil Industry. Working Paper 50, Geneva: International Labour Office. Retrieved from https://www.global-labou r-university.org/fileadmin/GLU_Working_Papers/GLU_WP_ No.50.pdf.

Balogun, B. J. (2013). The consequentialist foundations of traditional Yoruba Ethics: An exposition. Thought and Practice, 5(2), 103-121.

Barrena-Martínez, J., López-Fernández, M., \& Romero-Fernández, P. (2017). Socially responsible human resource policies and practices: Academic and professional validation. European Research on Management and Business Economics, 23(1), 55-61.

Bauman, C., \& Skitka, L. (2012). Corporate social responsibility as a source of employee satisfaction. Research in Organizational Behavior, 32, 63-86.

Behrend, H. (1957). The effort bargain. ILR Review, 10(4), 503-515.

Belgrave, F., \& Allison, K. (2018). Introduction to African American Psychology: From Africa to America. Thousand Oaks: Sage.

Bible Hub. (2004-2019, New International Version- Romans, 12:19). Search, Read, Study the Bible in Many Languages. Retrieved from https://biblehub.com/nasb/romans/12-19.htm.

Blau, P. (1964). Exchange and power in social life. New York: Wiley.

Bochner, S., \& Hesketh, B. (1994). Power distance, individualism-collectivism, and job-related attitudes in a culturally diverse work world. Journal of Cross-Cultural Psychology, 21, 200-213.

Boverie, P., \& Kroth, M. (2001). Transforming work: The five keys to achieving trust, commitment, and passion in the workplace. In New perspectives in organizational learning, performance, and change. Cambridge MA: Perseus Publishing.

Brammer, S., Millington, A., \& Rayton, B. (2007). The contribution of corporate social responsibility to organizational commitment. The International Journal of Human Resource Management, 18(10), 1701-1719. 
Buchanan, A. (1990). Justice as reciprocity versus subject-centered justice. Philosophy \& Public Affairs, 19(3), 227-252.

Cartwright, S., \& Holmes, N. (2006). The meaning of work: The challenge of regaining employee engagement and reducing cynicism. Human Resource Management Review, 16(2), 199-208.

Chaudhry, A., \& Song, L. (2014). Rethinking psychological contracts in the context of organizational change: The moderating role of social comparison and social exchange. The Journal of Applied Behavioral Science, 50(3), 337-363.

Chazan, N. (1993). Between liberalism and statism: African political cultures and democracy. In L. Diamond (Ed.), Political culture and democracy in developing countries (pp. 67-106). London: Lynne Rienner.

Chidi, O., Badejo, A., \& Ogunyomi, P. (2011). Collective bargaining dynamics in the upstream oil and gas industry: The Nigerian experience. In Proceedings of the 6th African regional congress of the international labour and employment relations association.

Chinguno, C. (2013). Marikana massacre and strike violence postapartheid. Global Labour Journal, 4(2), 160-166.

Colson, E. (1974). Tradition and contract: The problem of order. Chicago: Aldine Publishing Company.

Consultancy. Africa. (2018). SSA employees prefer healthcare benefits over others in their benefits package. Consultancy. Africa. Retrieved from https://www.consultancy.africa.

Conway, N., \& Briner, R. (2005). Understanding psychological contracts at work: A critical evaluation of theory and research. Oxford: Oxford University Press.

Corpus Quran. (2009-2017, verse 42:40). Language Research Group University of Leeds. Retrieved from http://corpus.quran.com/ translation.jsp?chapter $=42 \&$ verse $=40$.

Coyle-Shapiro, J., \& Conway, N. (2005a). Exchange relationships: Examining psychological contracts and perceived organizational support. Journal of Applied Psychology, 90(4), 774.

Coyle-Shapiro, J. A., \& Conway, N. (2005b). Exchange relationships: Examining psychological contracts and perceived organizational support. Journal of Applied Psychology, 90(4), 774.

Coyle-Shapiro, J. A., \& Shore, L. M. (2007). The employee-organization relationship: Where do we go from here? Human Resource Management Review, 17(2), 166-179.

Coyle-Shapiro, J. A. M., \& Kessler, I. (2002). Exploring reciprocity through the lens of the psychological contract: Employee and employer perspectives. European Journal of Work and Organizational Psychology, 11(1), 69-86.

Coyle-Shapiro, J. A.-M., \& Parzefall, M. (2008). Psychological contracts. In C. L. Cooper \& J. Barling (Eds.), The SAGE handbook of organizational behavior (pp. 17-34). London: SAGE Publications.

Coyle-Shapiro, J. A. M., Pereira Costa, S., Doden, W., \& Chang, C. (2019). Psychological contracts: Past, present, and future. Annual Review of Organizational Psychology and Organizational Behavior, 6, 145-169.

Cropanzano, R., \& Mitchell, M. S. (2005). Social exchange theory: An interdisciplinary review. Journal of Management, 31(6), 874-900.

Csiernik, R. (2014). The stressful workplace. In R. Csiernik (Ed.), Workplace wellness: Issues and responses (pp. 3-14). Toronto, ON: Canadian Scholars' Press.

De Roeck, K., \& Maon, F. (2018). Building the theoretical puzzle of employees' reactions to corporate social responsibility: An integrative conceptual framework and research agenda. Journal of Business Ethics, 149(3), 609-625.

Dean, J. W., Brandes, P., \& Dharwadkar, R. (1998). Organizational cynicism. Academy of Management Review, 23(2), 341-352.
Delecta, P. (2011). Work life balance. International Journal of Current Research, 3(4), 186-189.

Donlan, W. (1998). Political reciprocity in Dark Age Greece: Odysseus and his hetairoi. In C. Gill, P. Norman, \& R. Seaford (Eds.), Reciprocity in ancient Greece (pp. 51-71). New York: Oxford University Press.

Dopamu, P., \& Alana, E. (2004). Ethical System. In N. Lawal, M. Sadiku, \& A. Dopamu (Eds.), Understanding Yoruba life and culture (pp. 65-80). Trenton, NJ: Africa World Press.

Dulac, T., Coyle-Shapiro, J., Henderson, D., \& Wayne, S. (2008). Not all responses to breach are the same: The interconnection of social exchange and psychological contract processes in organizations. Academy of Management Journal, 51(6), 1079-1098.

Ederer, F., \& Stremitzer, A. (2017). Promises and expectations. Games and Economic Behavior, 106, 161-178.

Eisenberger, R., Armeli, S., Rexwinkel, B., Lynch, P. D., \& Rhoades, L. (2001). Reciprocation of perceived organizational support. Journal of Applied Psychology, 86(1), 42-51.

Eisenberger, R., Huntington, R., Hutchison, S., \& Sowa, D. (1986). Perceived organizational support. Journal of Applied Psychology, 71(3), 500 .

Eisenberger, R., Malone, G., \& Presson, W. (2016). Optimizing perceived organizational support to enhance employee engagement. Society for Human Resource Management and Society for Industrial and Organizational Psychology, 2-22.

Elbra, A. (2017). Governing African gold mining: Private governance and the resource curse. London: Palgrave Macmillan.

Elebuibon, F. (2004). Yoruba numerology: The secret power of nine. Extracts provided by Obafemi Origunwa from Elebuibon Fayemi's paper at OgbeYonu Festival Program 2004. Retrieved from http://www.obafemio.com/blog/yoruba-numerology-the-secre t-power-of-nine-9.

Emerson, R. (1981). Social exchange theory. In M, Rosenberg \& R. Turner (Eds.). Social psychology: Sociological perspectives (pp. 30-65). New York: Basic Books.

Fabamise. (2018, March 20). Nigeria: Why crisis persists in oil, gas industry-PENGASSAN. All Africa. Retrieved from http:// leadership.ng/2018/03/20/why-crisis-persists-in-oil-gas-indus try-pengassan/.

Fajana, S. (2005). Industrial relations in the oil industry in Nigeria. Retrieved from https://www.ilo.org/sector/Resources/publicatio ns/WCMS_161189/lang-en/index.htm.

Fasola, F. (2015). The Holy Odu: A collection of verses from the 256 Ifa Odu with commentary. Scotts Valley: CreateSpace Independent Publication.

Fleming, P. (2005). Workers' playtime? Boundaries and cynicism in a "culture of fun" program. The Journal of Applied Behavioral Science, 41(3), 285-303.

Giannikis, S., \& Nikandrou, I. (2013). The impact of corporate entrepreneurship and high-performance work systems on employees' job attitudes: empirical evidence from Greece during the economic downturn. The International Journal of Human Resource Management, 24(19), 3644-3666.

Glavas, A., \& Kelley, K. (2014). The effects of perceived corporate social responsibility on employee attitudes. Business Ethics Quarterly, 24(2), 165-202.

Gouldner, A. (1960). The norm of reciprocity: A preliminary statement. American Sociological Review, 25(2), 161-178.

Graham, E., Ackah, I., \& Gyampo, R. (2016). Politics of oil and gas in Ghana. Insight on Africa, 8(2), 131-141.

Grimmer, M., \& Oddy, M. (2007). Violation of the psychological contract: The mediating effect of relational versus transactional beliefs. Australian Journal of Management, 32(1), 153-174.

Gyekye, K. (1992). Person and community in African thought. Person and community: Ghanaian Philosophical Studies, 1, 297-312. 
Gyekye, S. (2006). Organisational tenure and safety perceptions: A comparative anaylsis. Journal of Occupational Health and Safety-Australia and New Zealand, 22(4), 359-371.

Gyekye, A. S., \& Salminen, S. (2005). Responsibility assignment at the workplace: A Finnish and Ghanaian perspective. Scandinavian Journal of Psychology, 46, 43-48.

Gyekye, S. A., \& Salminen, S. (2009). Perceived organizational support: An African perspective. Journal of Applied Social Psychology, 39(11), 2651-2668.

Hartley, C. (2014). Two conceptions of justice as reciprocity. Social Theory and Practice, 40(3), 409-432.

Hilgard, E. (1980). The trilogy of mind: Cognition, affection, and conation. Journal of the History of the Behavioral Sciences, 16(2), 107-117.

Hofman, P., \& Newman, A. (2014). The impact of perceived corporate social responsibility on organizational commitment and the moderating role of collectivism and masculinity: Evidence from China. The International Journal of Human Resource Management, 25(5), 631-652.

Hofstede, G. (1984). Cultural dimensions in management and planning. Asia Pacific journal of management, 1(2), 81-99.

Hofstede, G. (1994). Cultures and organisations: Intercultural co-operation and its importance for survival. London: HarperCollins.

Hofstede, G. (2002). Cultures and organisations: Software of the mind. London: McGraw-Hill.

Hofstede, G. (2009). Geert Hofstede cultural dimensions. Retrieved from http://taylortraining.com/clients/mcc/Hofstede_Cultural_ Dimension_Explained(external).pdf.

Homans, G. (1961). Social behaviour: Its elementary forms: New York: Harcourt, Brace, and World.

Homans, G. (1974). Social behavior: Its elementary forms. Oxford: Harcourt Brace Jovanovich.

Houston, D. M. (2005). Work-life balance in the 21 st century. Worklife balance in the 21st century (pp. 1-10). London: Palgrave Macmillan.

Hydén, G. (1980). Beyond Ujamaa in Tanzania: Underdevelopment and an uncaptured peasantry. Berkeley, CA: University of California Press.

Idowu, E. (1962). Olodumare: God in Yoruba belief. London: Longman.

Ijatuyi-Morphé, R. (2014). Africa's social and religious quest: A comprehensive survey and analysis of the African situation. Baltimore, MD: University Press.

Industriall Global Union (2018). Precarious work destroying workers' lives in Nigerian oil and gas industry. Retrieved from http://www. industriall-union.org/precarious-work-destroying-workers-lives -in-nigerian-oil-and-gas-industry-0.

International Labour Organisation. (2017). World Employment Social Outlook. Trends 2017. Geneva: International Labour Office. Retrieved from https://www.ilo.org/global/research/global-repor ts/weso/2017/lang-en/index.htm.

International Labour Organization. (1999). Report of the director-general: Decent work. In Proceedings of the international labour conference, 87 Session, Geneva. Retrieved from https://www.ilo. org/public/english/standards/relm/ilc/ilc87/rep-i.htm.

Irwin, K. (2009). Prosocial behavior across cultures: The effects of institutional versus generalized trust. Altruism and prosocial behavior in groups (pp. 165-198). Bingley: Emerald Group Publishing.

Jameson, C. (2010). The short step from love to hypnosis: A reconsideration of the Stockholm syndrome. Journal for Cultural Research, 14(4), 337-355.

Johnson, J., \& O'Leary-Kelly, A. (2003). The effects of psychological contract breach and organizational cynicism: Not all social exchange violations are created equal. Journal of Organizational
Behavior: The International Journal of Industrial, Occupational and Organizational Psychology and Behavior, 24(5), 627-647.

Karenga, M. (1999). Odu Ifa: The ethical teachings. Los Angeles: University of Sankore Press.

Karenga, M. (2012, August 31). Ethical insights from Odu Ifa: Choosing to be chosen. Los Angeles Sentinel, p. A-7. Retrieved from https://ibw21.org/commentary/dr-maulana-karenga/ethical-insig hts-from-odu-ifa-choosing-to-be-chosen/.

Khomba, J. (2011). Redesigning the Balanced Scorecard model: An African perspective. PhD Thesis, University of Pretoria. Retrieved from https://repository.up.ac.za/handle/2263/28706.

Kolk, A., \& Rivera-Santos, M. (2018). The state of research on Africa in business and management: Insights from a systematic review of key international journals. Business \& Society, 57(3), $415-436$

Lahai, J. (2012). Youth agency and survival strategies in Sierra Leone's post-war informal economy. In M. Ensor (Ed.), African childhoods: Survival, education and peacebuilding in the youngest continent (pp. 47-59). Basingstoke: Palgrave Macmillan.

Lee, C., \& Bruvold, N. (2003). Creating value for employees: Investment in employee development. The International Journal of Human Resource Management, 14(6), 981-1000.

Lemarchand, R. (1989). African peasantries, Reciprocity and the market: The economy of affection reconsidered (Paysanneries africaines, réciprocité et marché: L'économie de l'affection réexaminée). Cahiers D'Études Africaines, 29(113), 33-67.

Linde, B. (2015). The value of wellness in the workplace: A perspective of the employee-organisation relationship in the South African Labour Market. Singapore: Springer.

Lister, A. (2011). Justice as fairness and reciprocity. Analyse \& Kritik, 33(1), 93-112.

Lucero, M., \& Allen, R. (1994). Employee benefits: A growing source of psychological contract violations. Human Resource Management, 33(3), 425-446.

Lum, L., Kervin, J., Clark, K., Reid, F., \& Sirola, W. (1998). Explaining nursing turnover intent: Job satisfaction, pay satisfaction, or organizational commitment? Journal of Organizational Behavior, 19(3), 305-320.

Lutz, D. (2009). African Ubuntu philosophy and global management. Journal of Business Ethics, 84(3), 313.

Luu, T. (2016). Psychological contract and knowledge sharing: CSR as an antecedent and entrepreneurial orientation as a moderator. Corporate Communications: An International Journal, 21(1), $2-19$.

Malinowski, B. (1922). Ethnology and the study of society. Economica, 6, 208-219.

Mangaliso, M. P. (2001). Building competitive advantage from Ubuntu: Management lessons from South Africa. Academy of Management Perspectives, 15(3), 23-33.

Marikana Commission Inquiry Report. (2015, March 31). Marikana Commission of Inquiry. Retrieved from https://www.sahrc.org. za/home/21/files/marikana-report-1.pdf.

Matory, J. (2019). Oduduwa's chain: Locations of culture in the Yoruba-Atlantic. African and Black Diaspora: An International Journal, 12(1), 109-113.

Matten, D., \& Moon, J. (2008). Implicit and explicit CSR: A conceptual framework for a comparative understanding of corporate social responsibility. Academy of Management Review, 33(2), 404-424.

Mauss, A. (1969). Dimensions of religious defection. Review of Religious Research, 10(3), 128-135.

Mbigi, L. (2005). The spirit of African leadership. Johannesburg: Knowledge Resources.

Mbigi, L., \& Maree, J. (2005). Ubuntu: The spirit of African transformation management. Johannesburg: Knowledge Resources. 
Mbiti, J. (1969). African philosophy and religion. Nairobi: African Educational Publishers.

Mbiti, J. (1989). African religions and philosophy (2nd ed.). Oxford: Heinemann.

Menkiti, I. (1984). Person and community in African traditional thought. African Philosophy: An Introduction, 3, 171-182.

Metz, T. (2007). Toward an African moral theory. Journal of Political Philosophy, 15(3), 321-341.

Meyer, J. P., Stanley, D. J., Herscovitch, L., \& Topolnytsky, L. (2002). Affective, continuance, and normative commitment to the organization: A meta-analysis of antecedents, correlates, and consequences. Journal of Vocational Behavior, 61(1), 20-52.

Mirvis, P. (2012). Employee engagement and CSR: Transactional, relational, and developmental approaches. California Management Review, 54(4), 93-117.

Molm, L. (2010). The structure of reciprocity. Social Psychology Quarterly, 73(2), 119-131.

Morrison, E., \& Robinson, S. (1997). When employees feel betrayed: A model of how psychological contract violation develops. Academy of Management Review, 22(1), 226-256.

Mory, L., Wirtz, B., \& Göttel, V. (2016). Factors of internal corporate social responsibility and the effect on organizational commitment. The International Journal of Human Resource Management, 27(13), 1393-1425.

Murithi, T. (2006). Practical peace-making wisdom from Africa: Reflections on Ubuntu. Journal of Pan African Studies, 1(4), 25-35.

Murithi, T. (2008). African indigenous and endogenous approaches to peace and conflict resolution. In D. J. Francis (Ed.), Peace and conflict in Africa (pp. 16-30). London: Zed Books.

Murithi, T. (2009). An African perspective on peace education: Ubuntu lessons in reconciliation. International Review of Education, 55(2-3), 221-233.

Nelson, B., \& Lundin, S. (2010). An inspiring story about an African tradition of teamwork and collaboration: Ubuntu!. New York: Crown Publishing Group.

Ng, T. W., Feldman, D. C., \& Lam, S. S. (2010). Psychological contract breaches, organizational commitment, and innovationrelated behaviors: A latent growth modeling approach. Journal of Applied Psychology, 95(4), 744.

Ngunjiri, F. W. (2016). I am because we are: Exploring women's leadership under Ubuntu worldview. Advances in Developing Human Resources, 18(2), 223-242.

Nussbaum, B. (2003). African culture and Ubuntu: Reflections of a South African in America. World Business Academy Perspectives, 17(1), 1-12.

Nussbaum, B. (2009). Ubuntu: Reflections of a South African on our common humanity. In M. F. Murove (Ed.), African ethics: An anthology of comparative and applied ethics (pp. 100-110). Scottsville: Unviersity of KwaZulu-Natal Press.

O'Donohue, W., \& Nelson, L. (2009). The role of ethical values in an expanded psychological contract. Journal of Business Ethics, 90(2), 251-263.

Oke, M. (1988). Self-Interest as the Ground of Moral Obligation. Second Order, 1(2), 79-103.

Oluwole, S. (2017). Socrates and Orunmila: Two patron saints of classical philosophy (3rd ed.). Lagos: Ark Publishers.

Opoku, K. A. (1978). West African traditional religion. Singapore: FEP International.

Orvis, K., Dudley, N., \& Cortina, J. (2008). Conscientiousness and reactions to psychological contract breach: A longitudinal field study. Journal of Applied Psychology, 93(5), 1183.

Parrinder, G. (1969). Religion in Africa. Harmondsworth: Penguin Books.
Peterson, D. (2004). The relationship between perceptions of corporate citizenship and organizational commitment. Business \& Society, 43(3), 296-319.

Raja, U., \& Johns, G. (2010). The joint effects of personality and job scope on in-role performance, citizenship behaviors, and creativity. Human Relations, 63(7), 981-1005.

Raja, U., Johns, G., \& Ntalianis, F. (2004). The impact of personality on psychological contracts. Academy of Management Journal, 47(3), 350-367.

Redpath, L., \& Nielsen, M. (1997). A comparison of native culture, non-native culture and new management ideology. Canadian Journal of Administrative Sciences/Revue Canadienne des Sciences de l'Administration, 14(3), 327-339.

Restubog, S., Bordia, P., \& Tang, R. (2006). Effects of psychological contract breach on performance of IT employees: The mediating role of affective commitment. Journal of Occupational and Organizational Psychology, 79(2), 299-306.

Rhoades, L., \& Eisenberger, R. (2002). Perceived organizational support: A review of the literature. Journal of Applied Psychology, 87(4), 698.

Ridgeway, C. L. (2013). Why status matters for inequality. American Sociological Review, 79(1), 1-16.

Rivera-Santos, M., Holt, D., Littlewood, D., \& Kolk, A. (2015). Social entrepreneurship in sub-Saharan Africa. Academy of Management Perspectives, 29(1), 72-91.

Robinson, S., \& Morrison, E. (1995). Psychological contracts and OCB: The effect of unfulfilled obligations on civic virtue behavior. Journal of Organizational Behavior, 16(3), 289-298.

Rousseau, D. (1989). Psychological and implied contracts in organizations. Employee Responsibilities and Rights Journal, 2(2), 121-139.

Rousseau, D. (1995). Psychological contracts in organizations: Understanding written and unwritten agreements. London: Sage Publications.

Rousseau, D. (2000). Psychological contract inventory technical report. Retrieved from https://www.semanticscholar.org/paper/Psych ological-Contract-Inventory-Technical-Report-Rousseau/59f74 a582b2501bbe65cc3b33d3bf262038a74b0.

Rousseau, D., \& Wade-Benzoni, K. (1994). Linking strategy and human resource practices: How employee and customer contracts are created. Human Resource Management, 33(3), 463-489.

Ryder, G. (2015, March 31). Corporate Social Responsibility and decent work. Baltic Rim Economies, Issue No. 2. Retrieved from https://www.ilo.org/empent/Publications/WCMS.

Sahlins, M. (2017). Stone age economics. London: Routledge.

Schiele, J. (2000). Human services and the Afrocentric paradigm. Binghamton, NY: Haworth Press.

Schwartz, S. H., \& Sagiv, L. (1995). Identifying culture-specifics in the content and structure of values. Journal of Cross-Cultural Psychology, 26(1), 92-116.

Shahadah, A. (2017). African cultural complex: Personalities of African culture(s). African Holocaust. Retrieved from https://afric anholocaust.net/african_culture/.

Sheets, V. L., \& Braver, S. L. (1999). Organizational status and perceived sexual harassment: Detecting the mediators of a null effect. Personality and Social Psychology Bulletin, 25(9), $1159-1171$

Shen, J., \& Zhu, C. (2011). Effects of socially responsible human resource management on employee organizational commitment. The International Journal of Human Resource Management, 22(15), 3020-3035.

Shizha, E. (2016). African indigenous perspectives on technology. In G. Emeagwali \& E. Shizha (Eds.), African indigenous knowledge and the sciences: Journeys into the past and present (pp. 65-78). Rotterdam: Sense Publishers. 
Shonhiwa, S. (2006). The effective cross-cultural manager. A guide for business leaders in Africa. Cape Town: Juta.

Shore, L., \& Tetrick, L. (1994). The psychological contract as an explanatory framework in the employment relationship. In C. Cooper \& D. Rousseau (Eds.), Trends in organizational behavior (pp. 91-109). Oxford: Wiley.

Shore, L., Tetrick, L., Lynch, P., \& Barksdale, K. (2006). Social and economic exchange: Construct development and validation. Journal of Applied Social Psychology, 36(4), 837-867.

Shutte, A. (2008). African ethics in a globalising world. In R. Nicolson (Ed.), Persons in community: African ethics in a global culture (pp. 15-34). KwaZulu Natal: University of KwaZulu Natal Press.

Smith D. (2013, June 4). South African mining deep in crisis as ANC considers peacekeeping force. The Guardian. Retrieved from https://www.theguardian.com/business/2013/jun/04/south-afric an-mining-crisis-peacekeeping-force.

Stephens, C. (2016). The moderating role of perceived organizational support and perceived supervisor support on the relationship between teamwork behaviors and affective commitment. M.Sc. Thesis, San Jose State University. Retrieved from https://schol arworks.sjsu.edu/cgi/viewcontent.cgi article $=8326 \&$ conte $\mathrm{xt}=$ etd_theses.

Sundström, L. (1974). The exchange economy of pre-colonial tropical Africa. African Affairs, 75(299), 254-255.

Taylor, T., Darcy, S., Hoye, R., \& Cuskelly, G. (2006). Using psychological contract theory to explore issues in effective volunteer management. European Sport Management Quarterly, 6(2), 123-147.

Thang, N., \& Fassin, Y. (2017). The impact of internal corporate social responsibility on organizational commitment: Evidence from Vietnamese service firms. Journal of Asia-Pacific Business, $18(2), 100-116$.

Thomas, D. C., Fitzsimmons, S. R., Ravlin, E. C., Au, K. Y., Ekelund, B. Z., \& Barzantny, C. (2010). Psychological contracts across cultures. Organization Studies, 31(11), 1437-1458.

Triandis, H. (2001). Individualism-collectivism and personality. Journal of Personality, 69(6), 907-924.

Turaki, Y. (2006). Foundations of African traditional religion and worldview. Kampala: WordAlive Publishers.
Turker, D. (2009). Measuring corporate social responsibility: A scale development study. Journal of Business Ethics, 85(4), 411-427.

Udeze, B. (2009). Why Africa? A continent in a dilemma of unanswered questions. Bloomington: Xlibris Corporation.

Van Niekerk, J. (2013). Ubuntu and moral value. Ph.D. Thesis, University of the Witwatersrand, Johannesburg.

Voegtlin, C., \& Greenwood, M. (2016). Corporate social responsibility and human resource management: A systematic review and conceptual analysis. Human Resource Management Review, 26(3), 181-197.

Warfield-Coppock, N. (1995). Toward a theory of Afrocentric organizations. Journal of Black Psychology, 21(1), 30-48.

Wayne, S., Shore, L., \& Liden, R. (1997). Perceived organizational support and leader-member exchange: A social exchange perspective. Academy of Management Journal, 40, 82-111.

Welcome, M. O. (2011). The Nigerian health care system: Need for integrating adequate medical intelligence and surveillance systems. Journal of Pharmacy \& Bioallied Sciences, 3(4), 470.

Wike, R., \& Simmons, K. (2015). Health care, education are top priorities in Sub-Saharan Africa. Retrieved from https://www.pewre search.org/global/2015/09/16/health-care-education-are-toppriorities-in-sub-saharan-africa/.

Woermann, M., \& Engelbrecht, S. (2019). The ubuntu challenge to business: From stakeholders to relationholders. Journal of Business Ethics, 157(1), 27-44.

Yoon, J., \& Kim, J.-C. (1999). Organizational support in the workplace: The case of Korean hospital employees. Human Relations, 52, 923-944.

Zhao, H. A. O., Wayne, S. J., Glibkowski, B. C., \& Bravo, J. (2007). The impact of psychological contract breach on work-related outcomes: A meta-analysis. Personnel Psychology, 60(3), 647-680.

Publisher's Note Springer Nature remains neutral with regard to jurisdictional claims in published maps and institutional affiliations. 